\title{
「間」の感性情報†
}

\section{中村 敏枝*}

\section{1.はじめに}

ヒトの感性はファジィであるといわれる。確かに感 じ方はヒトそれぞれ時と場所で異なり、捉えどころが ないように思える。本稿で取り上げる「間」の感性も 然りである。間」という言葉で表現する内容自体があ まりにも広い。日本文化は「間」の文化といわれるだ けあって、あらゆる文化と関連し、「間」の概念そのも のが非常に多義多様でありファジィである。蒲生郷昭 ${ }^{[1]}$ は、『間」は本来空間的な隔たりを示すものであろう が、時間的概念に拡大し、微妙なタイミングを「間」 といい表わす。さらに、何もない空白の中に時間も空 間も超越した想像世界の可能性を意味するものでもあ る。そのために、「間」の概念がしだいに拡大され、曖 昧になっている』と指摘している。奥野健男 ${ }^{[2]}$ も「間」 という概念は、きわめて曖昧模糊として、その実体が 㨡めないと述べている。

したがって、「間」は科学的には取り扱えないものと されてきた。南 博 ${ }^{[3]}$ は「間」は休止、沈黙、間妳のよ うな物理的、生理的な過程でなく、形やことばでは表 現できない体験であると言い、生田久美子 ${ }^{[4]}$ は伝統芸 道における「間」とは、機械的に測れるものでも、数 量に換算されるものでもないと言っている。また、川 口秀子 ${ }^{[5]}$ は理屈にあわない、理屈で割り切れないからこ そ「間」なのだと断言する。

いわくいい難いとされてきた、あまりにも神秘的に 扱われ過きてきた感のある「間」であるだけに、極め てファジィであって量的に扱いようがないように思え る。とはいえ、誰にとっても少なすぎ空白や多すぎ る炇白は快いものではない。適切なサイズの「間」を われわれの感性は求めている。近年上く耳にする人工 アナウンスの「間」の覀さに不快感や違和感を党えた 経験は少なくないであろう(6)。多くのヒトに共通する丁 度よいと感しられる「間」があるならば、そこに何ら かの法則性を見出し、「間」の感性を定量的に追究する ことが可能なのではないだろうか。

$\dagger$ Sensuous Information Transmitted by " $M a$ " Toshie NAKAMURA

* 大阪大学大学院人閻科学研究科

Graduate School of Human Sciences, Osaka University
空間的・時間的な「間」は物理的には‘無’あるいは定 常的な状態である。少ない空間や時間の中に可能な限 り多量の情報を詰め込もうという経済性・効率性優先 の観点からすれば、「間」は無駄なものと軽視されるか もしれない。しかし、心理的には「間」は‘有’上上の効 果を持つ。このことを改めて認識し定量的研究を行う ことは、モノつくりの設計の中に快適な「間」を取り 入れるためにも必要であり、人工環境が益々大きなウ エイトを占める現状において意義のあることと思われ る。

本稿では「間」の感性について従来の定性的論述を 紹介し、「間」の重要性と概念の広さを示したうえで、 時間的な「間」に関して行ってきた定量的研究につい て概観する ${ }^{[7]-[10] 。}$

\section{2.「間」の感性}

白石大二 ${ }^{[11]}$ は「間」を含む成句・複合語を 150 以上挙 げているが、「間を合わせる」、間がいい」、間のびし た」など多くの言葉がある。その事実が示すように、 音楽、スピーチ、演劇、スポーツ、美術、建築、文学 などのほか、対人関係や礼儀作法まで我々の生活全般 において間」は重梘されている。したがって、芸談、 文芸論、芸術論、武芸談として、体験談や精神論の形 で「間」は定性的にしばしば論しられてきた。

例えば、舞踊家の「間」に関する芸談は多い ${ }^{[5][12][13] 。 ~}$ よく引用される例であるが、尾上菊五郎 ${ }^{[14]}$ は彼の著書 『芸』の中で九代目団十郎の言を伝えて「間」の重要 性を述べている。踊りの「問」に、教えられる「間」 と教えられない「間」の 2 種類あって、とりわけ大切 なのは教えられない方の「間」であるが、これを「魔」 と書くというのである。

狂言作者の竹柴蟹助は㭛を入れる「間」の難しさを 話した後、歌舞伎を「間の芸術」であると述へている [15]。

奇席の芸における「間」の重要性については亦井啓

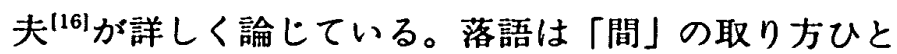
つで客の笑いを取れるか否かが決まる。落語作家の小 佐田定雄 ${ }^{[17]}$ は、演芸評論家に「間」がとれていないと 言われていた落語家が確実にテンポの楥急を身につけ るようになって、独特の「間」で笑いをとることがで 
きるようになった例を紹介している。

スポーツ、特に武道研究の領域においては「間」を

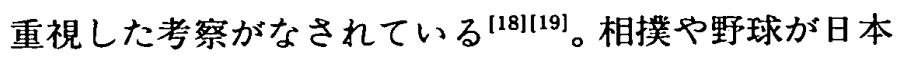
人に愛好されるのは、間」によるものではないかとい $j^{[2][20]}$ 。

話ことばにおける「間」の取り方の重要性を述へた

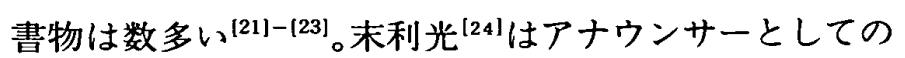
30年の経験に基づいて、話ことばにおいて「間」の問 題ほど大切なものはないと断言すると共に、文章を朗 読するとき上手に「間」を取ることによって、無理な く感情の表現ができると述べている。また、「間」の取 ク方の巧みさで有名だった徳川夢声の話術は「間の芸 術」と言われているが ${ }^{[25] 、}$ 彼自身も著書の中で、言葉 と言葉との句切れをつけるための初歩的な「間」のほ かに、張り詰めた神経を鋭敏に働かして正確無比に適 不適を計る「沈黙の時間」としての「間」の大切さを 説き、「話術」とは「マ術」なりと述べている ${ }^{[26]}$ 。

音楽における「間」は、日本の伝統音楽について論 ずる時には、最も重要な要素の一つとして必ず挙げら れる ${ }^{[1][27]}$ 。また、西洋音楽で「間」の効果を狙った作 品の例としてシューベルト作曲「Du bist die Ruh」を 挙げることができる ${ }^{[24]}$ 。

以上、主に時間的な「間」に関する定性的記述の例 を紹介したが、建築や絵画などの空間的な「間」も数 多く論しられている ${ }^{[28][29]}$ 。また、剣持武彦 ${ }^{[30]}$ は広く「間」 をとりあげて比較文化論を展開している。

このように重要性が論しられる「間」について定量 的研究を試みるために、筆者は時間的な「間」に焦点 を絞り、音楽と音声における「間」の心理学的研究を 進めてきた。

\section{3 . 「間」の感性の㨽定}

「間」の長さというのはどれくらいが適当なのか。 この問に答えるために、音楽やスピーチにおいて丁度 よいと感しられる「間」の長さを調べる実験を行なっ $た^{[31][33]}$ 。西洋音楽、日本の伝統音楽、スピーチなど 12 種類の刺激を使用し、音源やテンポなどの条件を変え て全部で30条件の聴取実験である。音楽はミュージッ クコンピュータを用いた自動演奏音と観世元正による 謡「鶴亀」の一部、スピーチはNHK のアナウンサー による天気予報と小説の朗読、並ひに、刺激 S1 (読点) と刺激 S2 (句点)である。各刺激について、「間」の部 分を 6 ～種類の長さに変えた刺激を呈示し、被験者 は「間」の部分が短すぎるか、丁度よいか、長すぎる かを判断した。実験に参加した被験者は452名(音楽専 攻生188名と一般学生264名) である。

1 条件につき $72 \sim 90$ 名の被験者の判断分布に基づき、
‘丁度よい長さ’を算出した。ファジィで量的に擸みどこ ろがないように思える「間」であるが、実験結果は非 常に安定していた。被験者群が異なっても、刺激が同 しであれば間」の值は常にほほ一定であった。テン ポが速くなると少し「間」が短くなる傾向はあったが、 拍が「間」の長さを決定するのでないことは明らかで あった。音楽専攻生と一般学生の間にも系統的な差は なく、音楽的訓練の影響は見られなかった。被験者は 呈示された曲を知らず、楽譜を見るのでもないので、

‘丁度よい長さ’には無数の可能性がある。それにも拘わ らず結果の一致が見られることは、丁度良いと感じら れる「間」の長さが共通した感性に支配されているこ とを示す。また、刺激の時間的文脈が変化すると結果 も規則的に若干変化した。これらの事実は「間」の感 じ方に一般性・法則性があることを示し、「間」を規定 する要因を科学的に追求し得ることを示咬するもので ある。

短い「間」から長い「間」まで、「間」の長さが多様 であることは日常経験するところである。しかし、そ の多様性の裏には規則性が潜んでいることが明らかに なった。

実験で用いた 30 種類の刺激から得られた結果は、0.35 秒前後、0.7秒前後、1.4秒前後という 3 つの群に分け ることができ、倍数関係の法則性を示した。

\section{4.「間」亡呼吸}

「間」の長さが上記のような安定性と規則性を示す のは「間」の感性が七トの生理的基盤に支配されてい るからではないかと推测される。音楽や舞踊にかかわ

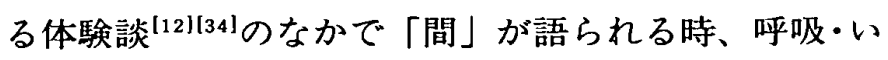
きという㗚がよく登場することに示唆を得て、音楽 聴取時における呼吸測定の実験を行った ${ }^{[35][36] 。 ~}$

呼吸測定のために用いた曲はフェッシュ作 SONATA やグラナドス作 SARDANA など 4 種類である。間」 の長さを变え、それぞれ 6 通りの演奏音をスピーカで 呈示した。呼吸の测定には胸部呼吸ピックアップを用 い、呼吸波形を演奏音と共にペンレコーダで描かせた。

表 1 に示すように、呼吸波形に基づいて算出した音 楽聴取時の一呼吸の平均長は約 2.9 秒で、どの刺激の場 合もほほ同じであった。前述の聴取実験で得られた「間」 の長さ1.4秒は、ほほ半呼吸の長さに一致する。安静時 の呼吸数はおよそ15回／分とされているので（一呼吸 の長さ 4 秒)、本実験でみられた音楽聴取時の呼吸は安 静時に比べ若于速めであるといえよう。

図 1 は演奏音における「間」と呼吸波形の関係の一 例を示したものである。波形の上端は吸気から呼気へ の変わり目、下端は呼気から吸気への変わり目を表わ 
表 1 音楽聴取時の一呼吸の辰さ

\begin{tabular}{l|c}
\hline \multicolumn{1}{c|}{ 刺 激 } & 一呼吸の長さ \\
\hline フェッシュの sonata & 2.80 秒 \\
クラナドスの Sardana & 2.98 秒 \\
刺激A & 2.90 秒 \\
刺激B & 2.89 秒
\end{tabular}

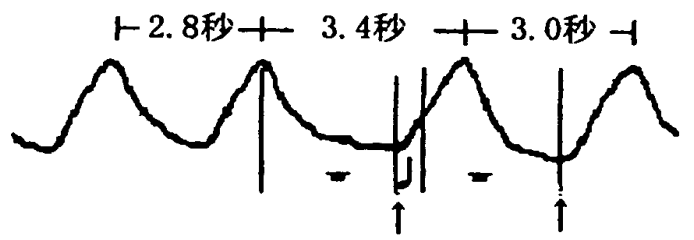

图1 演奏音における「間」と呼吸の同期

す。「間」の部分の演奏音の長さは音符 (『) で示す通 クである。図から「間」と呼吸とが同期する傾向が見 られる。すなわち、「間」の部分では呼吸を調整して、 呼気から吸気、あるいは、吸気から呼気への变化点と 「間」の終わりを一致させるケースが多く見られた(図 中の知印)。したがって、「間」が長い部分では呼吸を 止めて次の音の出るのを待つことになり、一呼吸の時 間が他の部分におけるよりも若干長くなる傾向があっ た。

実験結果が示唆するように「間」の感性の根底に呼 吸があるとするならば、「間」の長さは一呼吸の長さを 基準としていると予测される。演奏者の取る「間」の 長さを测定した結果からも同しことが言える。能「石 橋」の中に、長い「間」が取られることで有名な箇所 がある。吉川英史 ${ }^{[37 \mid}$ が『音がないけれども、その効果 からいえば100人のオーケストラがトウッティ（総奏） で演奏した音以上に緊張感を与えるものだと思う』と 述へているほど効果的な「間」の部分である。舞台記 録のビデオテープからこの箇所の「間」の長さを測定 した結果は 3 秒の倍数あるいは約数のみであった|381。 一番長い約12秒の「間」は一呼吸の 4 倍の長さに符合 する。

\section{5 .「いきの合う」現象}

「間」の根底に呼吸の存在があることが上述の実験 結果から確認できた。演奏者のとる「間」が呼吸と同 期し、その演奏を閏く聴取者の呼吸が演奏音に同期す る。このような、呼吸を基礎とした演奏者と聴取者の 関係が浮かんでくる。「いきが合う」と一般に言うが、 情報の送り手と受け手の間で文字どおり呼吸の合う場 面が展開されるものと思われる。コンサートホールな どでじかに演奏者の息吹を感しられる場面ではこの関
係はもっと強いと予想できる。また、演奏者間でも呼 吸に基づくことによって演奏音をうまく合わせること ができるのではないだろうか。このような「いきの合 う」場面を実験で確かめてみた。

シューベルト作曲「Du bist die Ruh」を歌唱中の歌 手の呼吸ならびにピアノ伴奏者の呼吸を测定した ${ }^{[39] 。}$ 歌手と伴奏者は防音室内で胸部呼吸ピックアップを装 着して演奏した。呼吸と歌声の波形がデータレコータ に同時に記録された。歌手には時々極めて大きな吸気 が見られる。その時、伴奏者の呼吸は必ず大きく变化 しており、伴奏者の呼吸は歌手の呼吸の大きな变化に 対応していることがわかった。図 2 に示すように、間」 の箇所においてはこの傾向が特に著しい。また、伴奏 者の呼気あるいは吸気と歌手の「間」の終わりは同期 している。歌手は大きく息継ぎをするこによって間」 を終わらせ、伴奏者は歌手の呼吸をうかがいながら自 分の呼吸を調整して伴奏音の「間」を歌唱の「間」に 合わせているといえよう。呼吸の同期によって演奏者 間で演奏音をうまく合わせることができる様が確認で きた。

同様に、歌唱中の歌手と対面聴取中の聴き手の呼吸 を测定した。結果の一部を図 3 に示す。聴き手の呼吸 は比較的規則的な波形を示すが、歌手が大きく呼吸す る箇所では聴き手の呼吸にも変化が見られた。図に示 すように、間」の箇所においてはこの傾向が特に著し い。「間」の部分で聴き手は息を止めて緊張状態にあり、

\section{歌手の呼吸}

伴奏者の呼吸

歌声の波形

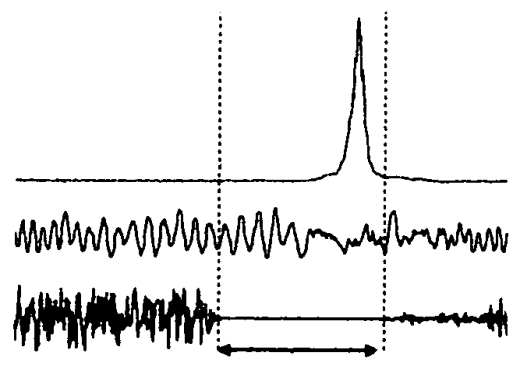

第61小節の「間」

図 2 「間」における歌手と伴奏者の呼吸の同期

歌手の呼吸

聴取者の呼吸

歌声の波形

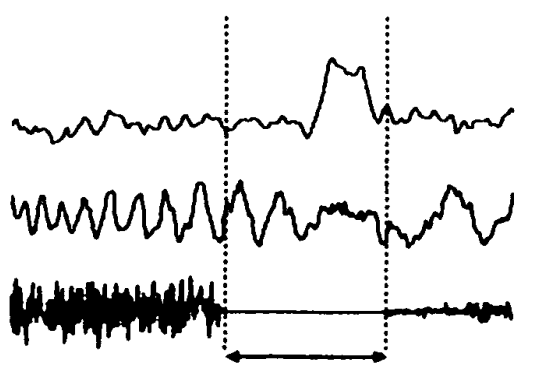

第61小節の「間」

図 3 「間」における歌手と聴取者の呼吸の同期 
朗読者の呼吸

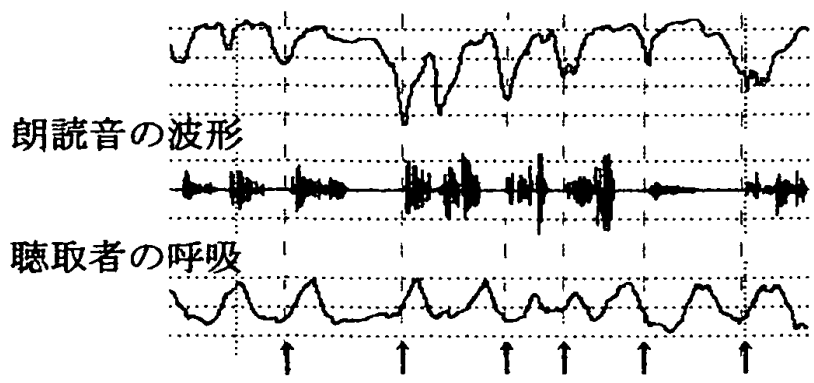

図 4 「間」における朗読者と聴取者の呼吸の同期

歌手と「いきを合わせ」ていることがわかる。

スピーチ聴取時の呼吸についても「いきの合う」現 象を確かめることができた ${ }^{[401[41]}$ 。困 4 は朗読者と対面 聴取者の呼吸を測定した結果の一例である。「間」の終 点で朗読者の呼吸変化と聴取者の呼吸変化が同期する 傾向がみられる (矢印)。

「いきが合う」と一般にいうが、情報の送り手と受 け手の間で文字通り呼吸の合う場面が展開されること が確認できた。感情の伝達がうまくいったために呼吸 が合い、呼吸が合ったために感情の伝達が更にうまく いく。このように、呼吸を介して感情伝達が深まる過 程が展開するのではないだろうか。そのような呼吸の 一致を導き出すのに「間」が大きく貢献しているとい えよう。

\section{6.「間」のゆらぎ}

前述のように、心理実験の結果に基づいて多数の被 験者の判断分布から算出した丁度良い「間」の長さは 極めて安定した值を示す。この值は多数のヒトの感性 の代表值で、いわば「間」の基準值ともいうべきもの である。「間」の感性が万人に共通したところがあるか らこそ代表值が常にほほ同じ長さになるといえる。し かし、当然ながら各個人が良いと感じる「間」の長さ は基準值を中心にゆらきをもっている。日常生活の体 験でも、人によって「間」の取り方が長い人や短い人 がいて、「間」が合わないために会話が弾まないことが ある。「間」の個人差を検討するために、間」と関係 があるのではないかと思われる精神テンポ（各人に固 有のテンポ）を測定した ${ }^{[42]}$ 。精神テンポの測定によく 用いられる打鍵法を用い、遅くも速くもない気持ちの よいテンポでキーを打つよう被験者に要求した。その 結果、精神テンポと「間」の長さの相関係数は $\mathrm{r}=.675$ となった。すなわち、精神テンポが遅い者ほど長い「間」 をとる傾向がみられた。また、別の実験で、精神テン ポの遅い者ほど、聴取上'丁度よい’と感じる「間」が長

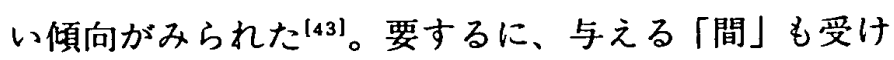

る「間」も、精神テンポの遅い者はど長い「間」を良 しとする傾向があるといえる。

また、基準になる「間」からのゆらぎは芸術的な「間」 にとって重要である。「絶妙の「間」」と呼ばれる芸術 的・名人芸的な「間」は基準值からの微妙なずれによっ て作り出されるものであろう。必ずしも最適の「間」 をとらず、予期する「間」から微妙にずれることによっ て生ずる緊張、弛緩、意外性の上手な組み合わせの効 果、それが芸術的・名人芸的な「間」ではないだろう か。

筆者は音楽や音声における「間」の定義を、『先行す るフレーズあるいは音群の内容と意味を把握し理解す ることを可能にし、且つ、うまく次の音群につないで いくのに必要にして十分な時間、さらには、コミュニ ケーションの送り手と受け手のあいだの感性情報伝達 のために最適な時間』としている。したがって、「間」 の長さは先行する音群の長さ、速度、内容、「間」の持 つ意味などによって系統的に変化し、「間」の基準値を 中心にゆらぎを呈すると考えられる。聴取実験の結果

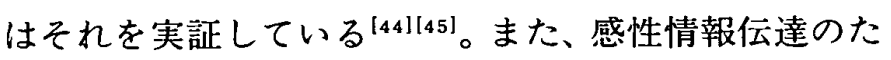
めに「間」のゆらぎの果たす役割は次に述べるように 大きい。

\section{7 . 朗読における感情表現と「間」}

スピーチにおいて「間」が必要であることはいうま でもないが、単に言葉の区切りや息継ぎのために不可 欠の時間というだけではない。感情表現の手段の 1 つ として重要な役割を担っていると考えられる。朗読者 の意図する感情表現と「問」の長さの関連を実証する ために実験を行った ${ }^{[46]}$ 。実験素材として、内容上、感 情を込めないであろうと考えられる「天気予報」、なら びに、朗読者の意図によって感情表現を変化させ易い
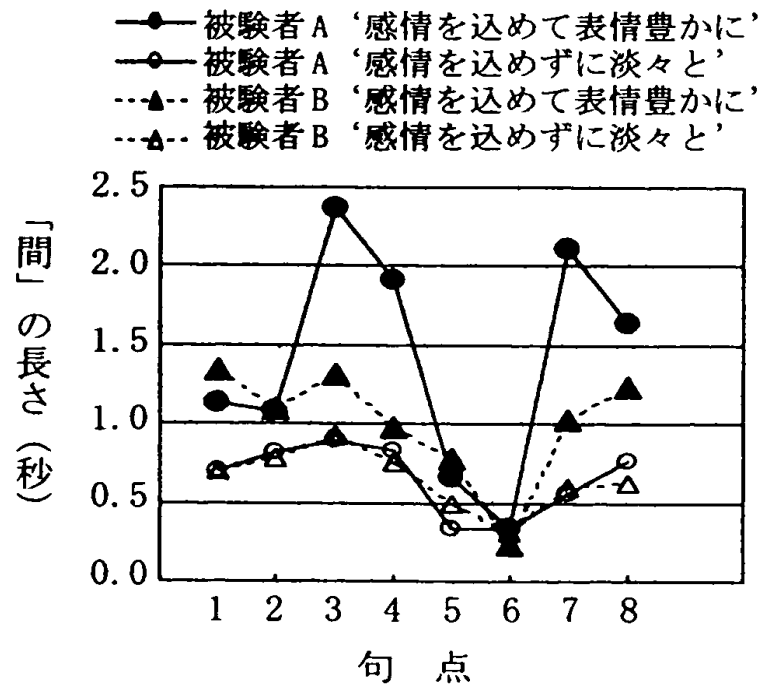

図 5 朗読における「間」の長さ 
「童話」を素材として実験を行なった。童話に関して は、感情を込めずに淡々と朗読’と感情を込めて表情豊 かに朗読’ 2 条件を設けた。大学生（18～24藏）の男 性 8 名と女性 5 名、50藏台の女性1名の計14名が朗読者 として参加した。

結果の一例を図 5 に示す。「間」と感情表現の間には 明らかな関係が見出された。すなわち、発話速度はど の朗読でもほほ同しであるが、間」の長さは、感情を 込めて表情豊かに朗読すすることを意図した時の方が感 情を込めすに淡々と朗読した時よりも顕著に長く、か つ、長短の变動と個人差が大きかった。

\section{8. 日本語と英語の「間」の比較}

日本人が「間」を特別重要視する背景として、別宮 貞徳 ${ }^{[47]}$ は日本語のリズムを挙げている。彼は日本語の 特徵として強弱のアクセントがないということと各音 節を発音するのに要する時間がほほ等しいということ をあげ、それが間」を必要にしていると指摘してい る。外国語には長短とか強弱とか音節そのものに変化 があるから、それを素材としてリズムを作ることがで きるが、日本語には長短も強弱もないために「間」を おくことがどうしても必要であるというのである。英 語を母国語とするヒトと話していて、言葉と言葉のあ いだに「間」がないので時々いらいらしてくるという 直塚玲子(48)の体験談からもうかがえるような、間」の 相違があると思われる。

これを定量的に検証するために、プロの朗読者のと る「間」の長さについて英語と日本語の比較を行なつ た ${ }^{[49]}$ 。用いた刺激は宮沢賢治の 5 つの作品である。対 訳された日本語と英語のそれぞれをプロの朗読者が母 国語で行った朗読音を素材として用いた。全部で各337 箇所の句点の測定値を得た結果を図 6 に示す。日本語 の「間」の長さは英語のそれよりも明らかに長い。全 ての統計値がその傾向を示している（例えば、「間」の

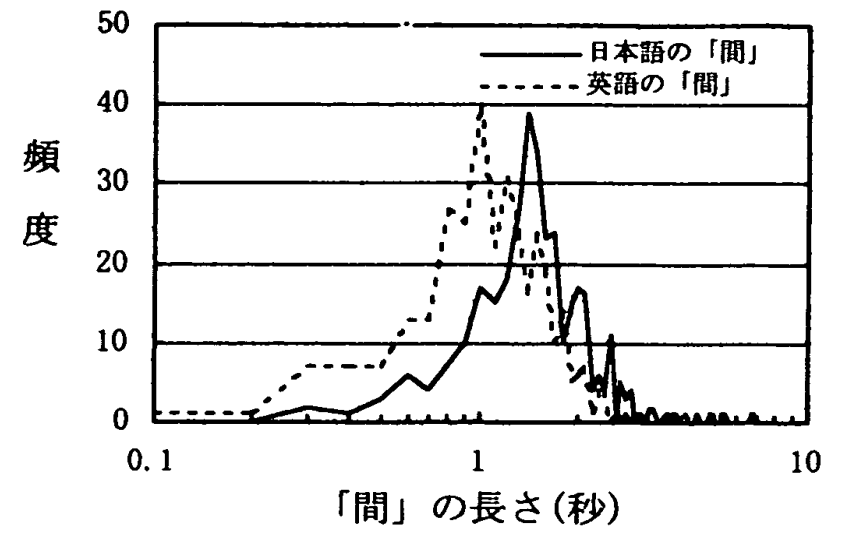

图 6 日本語朗読と英語朗読における「間」の比較

\section{9.「間」の効果}

「間」の長さの長短、適・不適が心理的にどのよう な効果を及ほすかを調べる実験を行った ${ }^{501}$ 。用いた刺 激は音楽演奏、スピーチ、落語などである。被験者は 音を閭いて受ける印象を形容詞尺度を用いて評定した。 NHK アナウンサーのスピーチを聴いた約100名の被験 者の評定結果の一部を図 7 に示す。元通りのスピーチ を聴いた被験者群の印象と,「間」の部分だけを短縮し たものを聴いた被験者群の印象には明らかに違いが られた。十分に「間」を取って話している方が、より 「きまじめ」「間（ま）のとりかたが良い」印象を与 えている。発話部分の速度は同じであるにもかかわら ず、「間」が短縮しただけでスピーチ全体のテンポが速 い印象を与えていることも興味深い。どの刺激の場合 も、「間」の部分のわずかの時間差を適確に反映した結 果となっており、われわれの「間」の感性の鋭さを示 す結果が得られた。

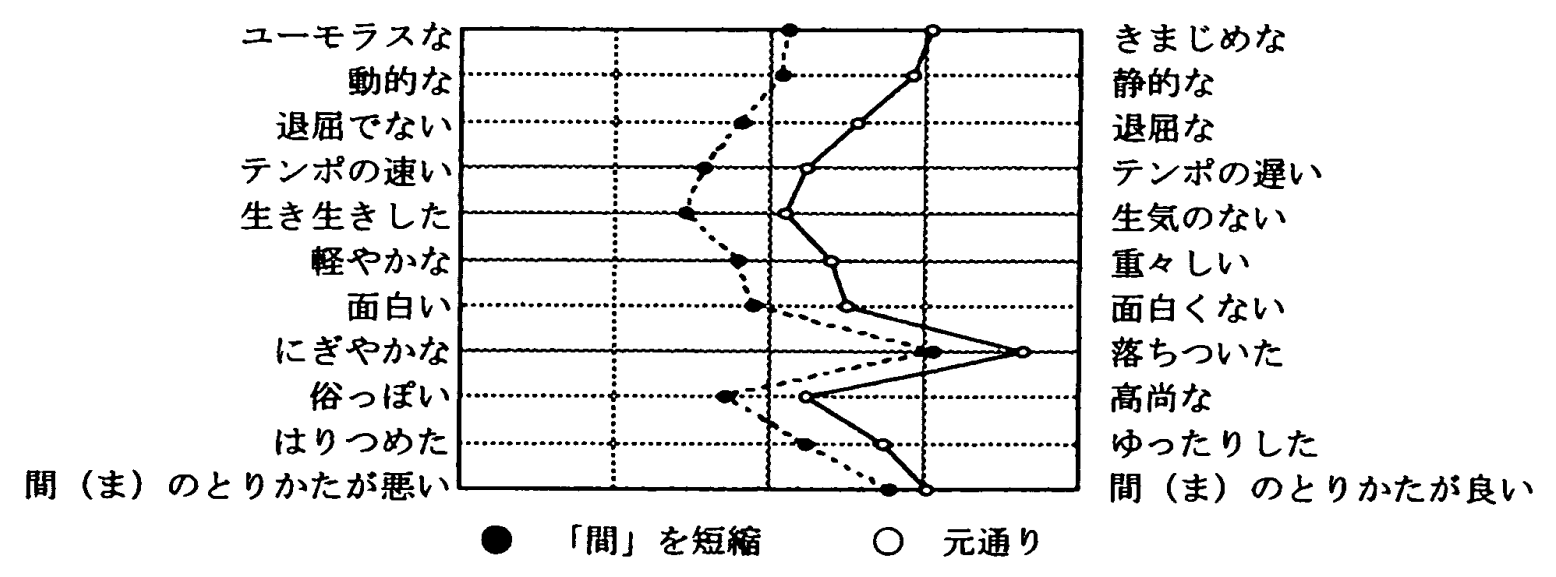

图7「間」の長短による印象の変化 


\section{0. おわりに}

「間」の定量化を試み、法則性を見いだすと共に、 「間」を規定する要因を探ることができた。「間」の感 性を科学的に追究することの可能性を確認し研究の第 一步を踏み出したばかりである。現在の課題として、 「間」に影響を及ほす諸要因を詳細に検討して総合し、 定量的モデルを構築することを目指している た、本稿では言及しなかったが、对話におけるように 情報の送り手と受け手のあいだの時系列的な相互関係 の反映としての「間」を追究し、円滑なコミュニケー ションに果なす「間」の役割を検討したい ${ }^{[54]-[56] 。}$

\section{参考 文 献}

[1] 蒲生鄉昭：日本音楽の間, 間の研究 (南 博編), 講 談社, 131-152, 1983.

[2] 奥野健男：“間”の構造一文学における関係素, 集英 社, 1983.

[3] 南 博: 序説一間とは何か, 間の研究 (南 博編), 講談社, 7-20, 1983.

[4] 生田久美子：「わさから知る」, 東京大学出版会, 1987.

[5] 川口秀子：日本舞䠃の間, 間の研究 (南 博編), 講 談社, 167-182, 1983.

［6］中村敏枝：“間”の感性，感性情報処理（電子情報通 信学会編)，オーム社，151-169，1994。

[ 7 ] 中村敏枝：音楽・スピーチにおける「間」，心理的現 在 (松田文子他編)，北大路書房，254-268，1996.

[8] 中村敏枝：「間」の解明, 感性の科学一感性情報処理 へのアプローチ(辻 三郎編), サイエンス社, 83-87, 1997.

[9] 中村敏枝：感性情報の伝達, ヒューマンインタフェー 又（田村 博編），オーム社，101-106，1998。

［10］中村敏枝：瞬時の音の世界一聴党情報処理一, 瞬間 情報処理の心理学 (海保博之編), 福村出版, 34-51, 2000.

［11］白石大二：間を含む成語の辞典，いき・いなせ・間， 現代のエスプリ，141，196-207，1979.

[12］利倉幸一：七世三津五郎, 舞踊芸話, 演劇出版社, 1977.

[13］郡司正勝：おどりの美学一間・移り,現代のエスプリ， $141 ， 181-184,1979$.

[14］尾上菊五郎：藝，改造杜，1947。

[15] 河竹登志夫：竹柴蟹助氏にきく，日本の美学，1(2), ペりかん社，17-24，1984。

[16］永井啓夫：寄席の芸 (間へのアプローチ), 間の研究 (南 博編), 講談社, 205-220, 1983.

［17］小佐田定雄：上方落語 米朝一門 おさだまり噺, 弘 文出版, 1991.

[18] 田中 守：剣道における「間」について一近世武芸伝 書を中心に一, 武道学研究, 15，31-32，1982.

[19] 袴田大蔵, 中野八十二, 志沢邦夫：剣道の間合いに関 する一考察, 武道学研究，9，63-65，1976.

[20] 塩澤邦彦：間の哲学, リーベル出版， 1986.

[21] 岡崎洋三：日本語とテンの打ち方, 晚㹂社, 1988 .

[22]さきえつや：こえことばのレッスン 3 表現編,晚成書
房， 1994

[23］櫻井弘：自分を磨く「話し方」,フォレスト出版, 1996.

[24] 末 利光：間の美学 日本的表現, 三省堂選書, 1991.

[25] 扇谷正造：“マ”ということ, 季刊「歌舞伎」, 9(4), 29-30, 1977.

[26] 徳川夢声：話術, 白揚社, 1996.

[27］上参郷㳓康：音楽の日本的趣味ーアジア諸国との比 較において一, 朝日アジアレビュー冬期号, 169-171, 1977.

[28］宮川英二：日本の美と文化, 11巻, 講談社, 1983 .

[29］中村溪男：東洋画に於ける間の芸術一とくに日本古 典絵画について, 間の研究 (南 博編), 講談社, 241-265, 1983.

[30］剣持武彦：「間」の日本文化，朝文社， 1992.

[31）中村敏枝：演奏時間における楽譜からの逸脱一“間” の知賞との関係一, 日本音響学会聴覚研究会資料, $\mathrm{H}$ $-87-32,1-6,1987$.

［32］中村敏枝：音楽、音声における“間”について一実験 (1) 一, 日本心理学会第52回大会発表論文集, 528, 1988.

［33］中村敏枝：音楽、音声における“間（ま）”について， 日本音響学会音楽音響研究会資料, MA88-22, $24-29,1989$

[34] 坂東三津五郎, 武智鉄二：芸十夜, 駸々堂出版, 1972.

[35] Nakamura, Toshie:Performed time duration for a note with aremarkablylong time value at the end of a phrase;the relation with time perception for an interval., The First International Conference on Music Perception and Cognition, 241-244, 1989.

［36］中村敏枝：音楽聴取時の呼吸と“間（ま）”の知賞と の関係，日本音響学会講演論文集，537-538，1989.

[37] 吉川英史, 神 正, 河竹登志夫：日本音楽をめぐって, 日本の美学，1(4)，ぺりかん社，10-26，1985.

[38］中村敏枝：コミュニケーションにおける“間（ま）” の科学と情報処理一“間”のもたらす意味とコミュニ ケーションー, イメージスクエア'92，77-86，1992.

[39）中村敏枝：音楽における「間」と呼吸について，日本 音響学会音楽音響研究会資料, MA94-16, 1-8, 1994.

[40］中村敏枝：メディアにおける“間（ま）の心理学的 研究，文部省科学研究費補助金重点領域研究平成 6 年研究報告書「感性情報処理の情報学・心理学的研 究」, 119-122, 1995.

[41] 中村敏枝，小森政勋，長岡千賀：「感情を込めた」朗 読と呼吸の関係, ヒューマンインタフェースシンポシ ウム’00論文集, 315-316, 2000 .

[42］中村敏枝，小森政嘼，長岡千賀，Maria Draguna： 「間」の取り方の個人差に関する検討, 日本心理学会 第65回大会発表論文集，340，2001.

[43］中村敏枝：“間（ま）"の科学，センシンク技術応用 研究会第72回研究例会資料, 1-10，1990.

[44] 中村敏枝：スピーチのテンポと「間」の長さ，日本心 理学会第62回大会発表論文集, 1998 .

[45] 中村敏枝：スピーチの内容と「間」の関係，日本心理 学会第61回大会発表論文集, $691 ， 1997$.

［46］中村敏枝,小森政嘼，長岡干賀：朗読における感情表 現一「間」の感性情報一, 日本心理学会第64回大会発 表論文集，592，2000。 
[47] 別宮貞徳：日本語のリズムと間,間の研究（南 博 編)，講談社，75-94，1983.

[48］直塚玲子：欧米人が沈黙するとき一異文化間のコ ミュニヶーション，大修館著店，1980。

[49] 中村敏枝, 小森政跼，長岡千贺：スピー千の「間」一 日本語と英語の比較一, 日本心理学会第63回大会発 表論文集，515，1999.

[50］中村敏枝：音声・音楽における “間（ま）”の効果, 日本心理学会第58回大会発表論文集, 738， 1994.

[51] 小森政嗣，長岡千驾，中村敏枝：「伝えたい」という 意図が間に及ほす効果, ヒューマンインタフェースシ ンポジウム’00論文集, 307-310，2000.

[52] 小森政跼, 長岡千賀, 河瀬 諭, Maria Draguna, 中村敏枝：発話速度がポーズの時間長に及ほす影響 ヒューマンインタフェースシンポジウム’01論文集, $217-220,2001$.

［53］小森政嗣，長岡千贺，Maria Draguna，中村敏枝： 文章構造が句点のポーズの時間長に及ほす影響, 日本
心理学全第65回大会発表論文集, 342, 2001.

[54] 長剛千贺, 小森政跼, 中村敏枝：自由对話における話 者交代の潜時と呼吸の関連, ヒューマンインタフェー スシンポジウム’00論文集, $311-314,2000$.

[55] 長掽千贺, Maria Draguna, 小森政解, 河瀨 諭, 中村敏枝：交替潜時の对話者間影锌, ヒューマンイン タフェースシンポジウム’01論文集, 221-224，2001.

[56］長岡千贺，小森政嘼，Maria Draguna，中村敏枝： 2 者対話における好意の表出一交替潜時を分析指標 として一, 日本心理学会第65回大会発表論文集, 341, 2001.

[問い合わせ先]

（2001年12月28日 受付）

大阪大学大学院人間科学研究科

中村 敏枝

TEL : $06-6879-8070$

FAX : 06-6879-8070

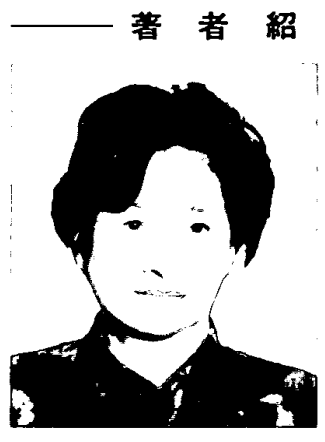

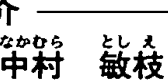

大阪大学大学院人間科学研究科

1966年大阪大学文学部卒業。1967年大

阪大学大学院文学研究科心理学尃攻中

退. 現在 大阪大学教授.【主要著货 (共

著)】「感性情報処理」舟子情報通信学会

編, オーム社, 1994. 「瞬間情報処理の心 理学」海保博之編, 福村出版, 2000. 「時

間と時一今日を豊かにするために一」広 中平佑他編, 日本学術事務センター, 2002. 他 